\section{Extensions of Foreign Universities in Israel: Transnational Education, a Form of Privatization?}

\section{Esther E. Gottlieb and Ruth Yakir}

Esther E. Gottlieb is director of the humanities and social sciences development program at West Virginia University. Address: WVU Research and Economic Development, P.O. Box 62 16, Morgantown, WV 26506. E-mail: <egottlie@wvu.edu>. Ruth Yakir is head of the department of educational administration at Kibbutzim College of Education. She is also academic director of Kidum Colleges in Tel Aviv. E-mail: <ruthy@mofet.macam98.ac.il>. Address: 149 Namir Road, Tel-Aviv 62507 Israel.

$\mathrm{T}$ his article is a first attempt to map the terrain of foreign higher education in Israel. It is based on interviews with students, lecturers, and administrators, a survey of materials published by 25 extension programs, and analysis of texts presented to consumers by 6 foreign university extensions.

This report attempts to present the case of transnational education from the point of view of a "host country"-Israel. ${ }^{1}$ Why has Israel become such an attractive market for institutions from the United States and Great Britain? What drives this market? The impetus is twofold: first, the evergrowing demand by Israelis for higher education degrees, by any means, and at any price; and second, the economics of the "home" institutions that are hungry for new markets. Hence, it would seem that Israeli consumers were driven to patronize a transnational system of tertiary education suppliers to satisfy their ever growing social demand for higher education. Is the Israeli case exceptional?

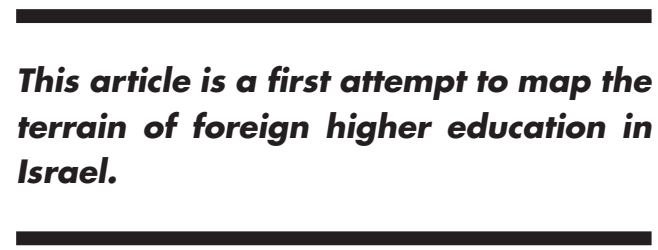

All institutions of higher education that grant academic degrees in Israel operate under the authority of the State Council of Higher Education (CHE), and are budgeted and partially financed by the State Planning and Grants Committee (PGC). Twelve years of schooling in Israel became free in the early 1980s (only 10 years are mandatory), and the system approached universal attainment of secondary education. The 6 universities and the 14 academic colleges that existed in 1992 proved unable to accommodate the deluge of new applicants and nontraditional students. As late as 1989, the CHE was still clinging to the view that the existing system could meet the demand for higher education - without the establishment of additional institutions-and recommended very strict examination of colleges applying for academic recognition. However, pressure from many directions was forcing the system to abandon the exclusivist tradition, which equates higher education with research universities, and to define most postsecondary institutions as academic.

In response to this situation, three sectors that had previously been nearly dormant underwent rapid development. First, the public college sector, consisting of postsecondary technological institutes, teachers colleges, and regional colleges, was upgraded. A second sector that has begun to come into its own as a result of heightened demand-especially in law, computer sciences, and business administration-is a new group of private colleges, whose tuition rates are at least double those in the traditional public-supported sector. A third sector is the transnational one to which this study is devoted.

A recent amendment to the Higher Education Law requires that foreign universities be licensed to operate specific programs, and sets down guidelines by which the extensions are required to abide. The most salient of these guidelines follow:

- The programs licensed in Israel should be identical to those at the home university. Graduates of the Israeli programs should be eligible to continue their studies at the home university according to the same procedures as "home" graduates.

- Quality control, evaluation procedures, entrance requirements, and staff appointments should be operated in Israel by the home university.

- The time required to complete an academic degree should be similar to the time required to complete a comparable degree in an Israeli university.

- Extensions of foreign universities in Israel will not operate in cooperation with a recognized Israeli institution of higher education unless the Council has given special permission to do so. Foreign extensions will not be recipients of public funds except in special circumstances.

- At least 30 percent of the program shall be taught by instructors from the home university. Twenty percent of the Israeli staff shall have the foreign extension as their main employer or will have held an appointment at the foreign university for at least four years. ${ }^{2}$

\section{The Pilot Study}

Texts published by the extensions in Israel were analyzed on the following dimensions: (1) programs of study, (2) degrees awarded, (3) language of instruction, (4) number of required semesters overseas at home university. Since it 
is difficult to judge the quality of a program from the promotional material, we checked the relative academic standing for U.S. institutions, using the Carnegie Foundation classification, and the Good University Guide for British institutions. ${ }^{3}$ Two universities, one from South Africa and one from Eastern Europe were not included in the analysis. We did three in-depth interviews with staff and students to try to understand what motivates students and teachers. We also wanted to know what motivates the home university and the local administration.

\section{Provisional Results}

We found that the foreign universities offer degrees in the areas of highest demand. Business and management head the list with 17 second-degree and 9 first-degree programs. Masters degrees in education are also in demand-there were 10 in the present sample. Many transnational programs offer degrees in fields that do not exist in the traditional Israeli higher education system - such as expressive art therapy, tourism, and sports management, and a master's degree in optometry.

\section{Foreign university extensions have at- tracted considerable criticism from the ranks of traditional academe.}

We were impressed with the preponderance of nontraditional students, students of minority, ethnic, and national backgrounds, new immigrants, and older adults with a great deal of professional and work experience. We do not believe that they are looking only for an "easy" way to get a higher degree, but one that would be intellectually challenging and able to meet their needs. Some mentioned that they were disappointed because so much English was required-something they hadn't expected. Most enthusiastic was the student who had spent the semester in Great Britain and thought that the learning experience in the "home" institute was worth the investment.

For the academic staff, teaching for the foreign university represented an extra source of income, and this fact was their main motivation. However, they also mentioned ties with British and U.S. colleagues from the home university as an important benefit. They also felt committed to their students-nontraditional students who would otherwise not have had a chance to pursue a higher education degree. In this regard they perceived their work as a contribution to the public good. These schools accept nontraditional students wishing to gain qualifications but who are unable to enter Israeli universities and are unable to study abroad due to work and/or family commitments.
Interviews with administrators (one Israeli and two British) highlight the fact that their main motive was income. However, we found that they also had strong ideological incentives-increased access to higher education for just the kind of population found in their programs, a desire to cooperate with the home university as a way of building understanding across national boundaries, and a belief that private entrepreneurs have a real contribution to make in cutting the State's costs of higher education and in encouraging the students to pay the bill. The very small sample (three administrators) may not be representative of the programs or their initiators.

Foreign university extensions have attracted considerable criticism from the ranks of traditional academe. One such criticism is that transnational higher education packages are really a form of cultural imperialismthe home country delivers a partial program that is "good enough for the natives." While this may be true of some programs, in the case of the institutions in our study, we found a real interest in cooperating and sharing with local providers. The foreign institutions involved local academic faculty in both curriculum planning and teaching. They viewed Israeli faculty as having outstanding abilities, which is not surprising since the Israeli academic profession ranks high in terms of research, publications, and its active presence on the international academic scene.

At present, although some of the transnational education businesses in Israel are really not very profitable, they persist in the belief that the future holds promise. Most institutions are concerned about quality issues; their "name brand" is important to them; and they want to deliver a good product to their clientele. All in all, transnational education in Israel is in great demand and institutions have more applications than they can serve. The foreign institutions in Israel answer a market need that cannot be satisfied by local institutions, and they are paving the way for privatization of higher education.

\section{Notes}

1. McBurnie and Pollock have suggested six different ways in which education is delivered transnationally. Their description reflects the home country (Australia) point of view of "exporting" education, mainly to the Asia Pacific region. See G. McBurnie and A. Pollock, "Transnational Education: An Australian Example," International Higher Education 10 (Winter 1998): 12-13.

2. See M. Chen, E. E. Gottlieb, and R. Yakir, "The Academic Profession in Israel: Continuity and Transformation," in The International Academic Profession: Portraits of Fourteen Countries, ed. Philip G. Altbach (Princeton, N.J.: Carnegie Foundation, 1996): 617-68.

3. See A Classification of Institutions of Higher Education, 1994 edition, The Carnegie Foundation for the Advancement of Teaching, and The Good University Guide, Times Special Report, May 23,1997. 